VERSLAS: TEORIJA IR PRAKTIKA / BUSINESS: THEORY AND PRACTICE

ISSN 1648-0627 / elSSN 1822-4202

http://www.btp.vgtu.lt

2015 16(1): 45-52

doi:10.3846/btp.2015.526

\title{
THE IMPLEMENTATION OF SOCIAL RESPONSIVENESS INITIATIVES: CASE OF LITHUANIA
}

\author{
Valentinas NAVICKAS ${ }^{1}$, Rima KONTAUTIENE $\dot{E}^{2}$ \\ ${ }^{1,2}$ Department of Economics, School of Economics and Business, Kaunas University of Technology, \\ K. Donelaičio g. 20, LT-44029, Kaunas, Lithuania \\ E-mails: ${ }^{1}$ valentinas.navickas@ktu.lt (corresponding author); ${ }^{2}$ rima.kontautiene@ktu.edu
}

Received 26 August 2014; accepted 09 October 2014

\begin{abstract}
A concept of social responsibility reflects public concerns and issues for a specific time, and these change with time. Various stakeholders as consumers, customers, employees, trade unions, communities, non-governmental organizations, foundations, donors, investors are more and more interested in the activities of companies (organizations), and influence on them in a variety of ways. Companies, for their part, also look for ways to meet the expectations of the public in the area of social responsibility. Corporate social responsiveness is an ability of business to respond to social pressure. The article analyzes the implementation of social responsiveness initiatives as organizational programs. Social responsiveness is understood as action dimension of corporate social responsibility. The paper deals with implementation of social responsiveness initiatives in Lithuania. Researched the socially responsiveness initiatives as organizational programs, the authors found that an active development of corporate social responsiveness positively influences on businesses and society relationship and contribute to sustainable development of region or country.
\end{abstract}

Keywords: corporate social responsibility, social responsiveness, stakeholder expectations, sustainable development, Lithuania.

JEL Classification: A13, M14, M20, Q01, Q56.

\section{SOCIALINIO REAGAVIMO INICIATYVŲ İGYVENDINIMAS LIETUVOJE}

\author{
Valentinas NAVICKAS ${ }^{1}$, Rima KONTAUTIENE $\dot{2}^{2}$ \\ ${ }^{1,2}$ Kauno technologijos universitetas, Ekonomikos ir verslo fakultetas, Ekonomikos katedra, \\ K. Donelaičio g. 73, LT-44029 Kaunas, Lietuva \\ El.paštas: ${ }^{1}$ valentinas.navickas@ktu.lt; ${ }^{2}$ rima.kontautiene@ktu.edu
}

Iteikta 2014-08-26; priimta 2014-10-09

\begin{abstract}
Santrauka. Socialinès atsakomybès koncepcija atspindi visuomenei tam tikru metu aktualias problemas ir lūkesčius, kurie laikui bėgant kinta. Ivairios suinteresuotos šalys: vartotojai, klientai, darbuotojai, profesinės sąjungos, bendruomenès, nevyriausybinès organizacijos, fondai, aukotojai, investuotojai - vis labiau domisi įmonių (organizacijų) veikla. Suinteresuotos šalys daro ịtaką ìmonių veiklai ir augimui. Imonès taip pat ieško sprendimų ir priemonių, siekdamos patenkinti socialinius visuomenès lūkesčius. Socialinis įmonių reagavimas - tai verslo atsakas ị socialinị spaudimą. Autoriai nagrinéja socialinio reagavimo procesus kaip organizacines programas ir veiklas siekiant igyvendinti socialinès įmonių atsakomybès principus ir patenkinti suinteresuotų šalių lūkesčius. Socialinis reagavimas suprantamas kaip socialinės įmonių atsakomybès veikimo dimensija. Straipsnyje analizuojama,
\end{abstract}

Copyright @ 2015 The Authors. Published by VGTU Press.

This is an open-access article distributed under the terms of the Creative Commons Attribution-NonCommercial 4.0 (CC BY-NC 4.0) license, which permits unrestricted use, distribution, and reproduction in any medium, provided the original author and source are credited. The material cannot be used for commercial purposes.

To link to this article: http://dx.doi.org/10.3846/btp.2015.526 
kaip igyvendinamos socialinio reagavimo iniciatyvos Lietuvoje. Išnagrinėję socialinio reagavimo iniciatyvas kaip organizacines programas autoriai nustatė, kad veikli socialinio įmonių reagavimo iniciatyvų plètra daro teigiamą ịtaką verslo ir visuomenés santykiams bei prisideda prie darnaus regiono / šalies vystymosi.

Reikšminiai žodžiai: socialinė ịmonių atsakomybè, socialinis reagavimas, suinteresuotų šalių lūkesčiai, darnus vystymasis, Lietuva.

\section{Introduction}

Being socially responsible means that organization complies not only with economic, but also with moral, ethical, and social standards, which are partially determined by stakeholder demands (Maignan, Ferrell 2001; David et al. 2005).Corporate social responsibility (CSR) suggests that businesses are responsible for assessing their impact on society (Mohr et al. 2001; Quazi 2003; Lockett et al. 2006). CSR is viewed as a subset of corporate obligations dealing with a company's voluntary and discretionary relationships with its societal and community stakeholders to minimize or eliminate harmful effects and maximize long run benefits to society (Mohr et al. 2001; Waddock 2004). An "action phase" of corporate social responsibility (Carroll 1979; Wood 1991) and a way to manage and respond to societal and stakeholder demands (Carroll 1979; Sethi 1979; Matten et al. 2003; Crampton, Patten 2008) is corporate social responsiveness. Responsiveness means that companies should take explicit and forward looking actions to respond and to deal with stakeholders and public policy issues (Waddock 2004). Corporate social responsiveness is about the process and implementation of socially responsible activities (Logsdon 2004). The initiatives of corporate social responsiveness have been described as being necessary strategic tools for gaining and sustaining a competitive advantage, as well as facilitating corporate social responsibility (Friedman et al. 2004). Waddock (2004) maintained that corporate social responsiveness was drawn from the experience of companies rather than from calls for more responsibility from scholars and activists. Businesses realize and take responsibility not only for the success of their activities, but also for the contribution to the development of a community, region and country. As stated Dillon et al. (2014), "the potential social impacts of business and society relations are a critical component of CSR that has been largely missing from organizational scholarship". Main motive of this paper is to analyze social responsiveness initiatives as organizational programs responding to stakeholders and public issues, and their implementation in Lithuania.

The object of the study is social responsiveness initiatives.

The purpose of the study is to analyze the implementation of social responsiveness initiatives in Lithuania.

The tasks of the study are:

1. To explore the aspects of corporate social responsibility;
2. To analyze processes of corporate social responsiveness as organizational programs;

3. To analyze corporate social responsiveness initiatives as organizational programs in Lithuania.

The methods of the study are systematic, logical and comparative analysis of scientific literature, analysis of statistic indices, the expert evaluation method.

\section{The aspects of corporate social responsibility}

According to the European Commission's definition (2011) corporate social responsibility (CSR) is "the responsibility of enterprises for their impacts on society". In conformity with OECD (2011), "corporate responsibility involves the search for an effective "fit" between businesses and the societies in which they operate". Corporate social responsibility is a concept whereby companies integrate social and environmental concerns in their business activities and in their relationship with stakeholders. For example, for dealing with social needs the company decides to go beyond the minimum legal requirements and obligations covered in the collective agreements. Corporate social responsibility provides the opportunity to coordinate economic, social and environmental objectives for large and small enterprises together with stakeholders. "CSR is, however, one of the most complex challenges facing businesses today. To many, it is a guiding principle that underpins corporate vision, strategy and decision-making. To others, it represents a series of emerging issues that must be "managed" by the company in order to maintain its "license to operate" (Streimikiene, Kovaliov 2007). Corporate social responsibility is based on three main elements: economic, environmental and social, which must be developed equally and in parallel (see Table 1) (Giziene et al. 2011).

A successful operative company adapts all of these aspects of social responsibility so that they may function in equilibrium. All these elements are significant to the development of sustainable business and must be developed equally and in parallel. That's why corporate social responsibility is considered to be an essential condition for sustainable development. Corporate social responsibility becomes an increasingly important concept both globally and within the European Union because it is a part of the debate about globalization, competitiveness and sustainability. The promotion of CSR indicates that the need to defend common values and to increase solidarity and cohesion is emerged. Although the concept of corporate social responsibility was 
used for the first time in the 1930s, so far it does not have one definition and an still discussed and on its content and scope. Generally it can be said that corporate social responsibility is ensuring the success of its business, including a wide variety of social and environmental issues in organization's activity. "The long-term success of the company depends on how it manages to integrate harmoniously into the environment and to assess internal and external stakeholder expectations. The relationship between the company and the surrounding environment should be formed on the basis of social responsibility" (Navickas, Kontautiene 2012). “...spreading CSR conception impels to ensure the implementation of needs and goals of all groups concerned" (Dagiliene 2010). Corporate social responsibility may be analyzed in two dimensions: internal dimension and external dimension. Each of the latter contains other several aspects, based on the concept of CSR (see Fig. 1) (Ruzevicius, Serafimas 2007). Social responsibility is consciously created economic, political, legal and moral relationship between the organization and the society, as well as its various structural forms; it's the ability to fulfill the duties and to assume the responsibilities for the public pressure in certain conditions (Pruskus 2003). The public wants to see "healthy" companies. A matter of the primary task and the obligation in activity of socially responsible companies is to manufacture products, to provide services, and so on. But society already requires more than produce or sell. A business has to make decisions both social as well as in the field of global environmental problems. Today business relationship is measured using the principles of humanism. Business is a product of society, affecting not only the people working on it, but also to the environment. Social responsibility shows the commitment of the company to maximize the beneficial effects and to minimize the negative impact on the public. No one company cannot completely distance from responsibility.

\section{Processes of corporate social responsiveness as organizational programs}

In the time of changing economic conditions being socially responsible businesses is much more important than ever before. According to Campbell (2007), "economic conditions - specifically, the relative health of corporations and the economy and the level of competition to which corporations are exposed, affect the probability that corporations will act in socially responsible ways". Also public expectations have exchanged, the expectations of customers, partners and employees have altered as well. In order to retain in ever changing environment of business the importance of conducting socially responsible policies has become necessary demand from society, other companies and governments in general. Corporate social responsiveness comprises of the capacity of business to respond to societal needs
Table 1. Main elements of CSR (adapted by Giziene et al. 2011)

\begin{tabular}{|l|l|l|}
\hline \multicolumn{3}{|c|}{ Corporate social responsibility } \\
\hline $\begin{array}{c}\text { Economic } \\
\text { responsibility }\end{array}$ & \multicolumn{1}{|c|}{$\begin{array}{c}\text { Environmental } \\
\text { responsibility }\end{array}$} & \multicolumn{1}{c|}{$\begin{array}{c}\text { Social } \\
\text { responsibility }\end{array}$} \\
\hline $\begin{array}{l}\text { Cost-effective } \\
\text { activities - } \\
\text { profitability. }\end{array}$ & $\begin{array}{l}\text { Knowing what envi- } \\
\text { ronmental impact } \\
\text { of human activities } \\
\text { (use of raw mate- } \\
\text { rials, environmental } \\
\text { pollution). }\end{array}$ & $\begin{array}{l}\text { Caring for } \\
\text { the welfare, } \\
\text { perfection and } \\
\text { motivation of } \\
\text { workers. }\end{array}$ \\
\hline $\begin{array}{l}\text { Competitive } \\
\text { products and } \\
\text { services. }\end{array}$ & $\begin{array}{l}\text { Constant improvement } \\
\text { of the activities. }\end{array}$ & $\begin{array}{l}\text { Support of open } \\
\text { communication } \\
\text { with stakeholders. }\end{array}$ \\
\hline $\begin{array}{l}\text { Reliability of } \\
\text { energy supply. }\end{array}$ & $\begin{array}{l}\text { Knowledge and } \\
\text { compliance of } \\
\text { environmental } \\
\text { legislation. }\end{array}$ & $\begin{array}{l}\text { Encouragement } \\
\text { of cooperation. }\end{array}$ \\
\hline $\begin{array}{l}\text { Financial risk } \\
\text { management. }\end{array}$ & $\begin{array}{l}\text { Evaluation and } \\
\text { observance of necessary } \\
\text { changes. }\end{array}$ & $\begin{array}{l}\text { Caring for the } \\
\text { needs of the } \\
\text { public and clients. }\end{array}$ \\
\hline
\end{tabular}

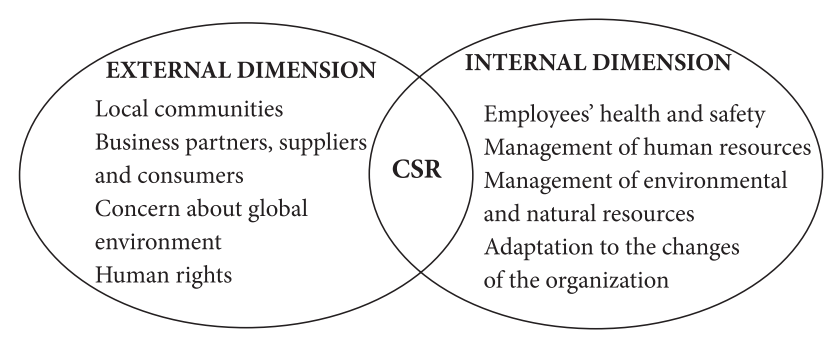

Fig. 1. Dimensions of CSR (adapted by Ruzevicius, Serafimas 2007)

thereby (partially) representing its relationship with society (Crampton, Patten 2008). It suggests that responsiveness means taking explicit and forward looking actions when addressing stakeholders and social/public policy concerns (Waddock 2004). This testified the ability of a business to survive through adaptation to its changing environment. "Responsiveness implies that companies monitor and assess environmental conditions, attend to stakeholder demands and design plans and policies to respond to changing conditions" (Fieseler et al. 2010). Corporate social responsiveness focuses on the processes for achieving a certain degree of social responsibility and "for determining, implementing, and evaluating the firm's capacity to anticipate, respond to and manage the issues and problems arising from the diverse claims and expectations of internal and external stakeholders" (Maurer 2007). Wood (1991) emphasized three main types of corporate social responsiveness processes: environmental management, issues management, and stakeholder management. But according to Maignan and Ralston (2002), Maignan and Ferrell (2004), Maignan et al. (2005), responsive practices introduced by businesses were much narrower in scope than the processes of corporate social responsiveness conceptualized by Wood (1991). 
Businesses designated responsiveness processes as organizational programs and activities aimed at implementing CSR principles and/or addressing specific stakeholder issues. Authors ascertained that companies the processes of corporate social responsiveness defined as specific activities such as quality management, ethics, or philanthropic programs, sponsorship, and volunteerism (see Table 2). Dentchev (2004) proposed that corporate social responsiveness could be seen as the moral obligations of business to address and resolve issues spanning beyond the boundaries of the organization. The programs of corporate social responsiveness are pointed to respond to stakeholders' needs and to contribute to resolving of social problems both inside and outside the company. Well-established corporate giving programs benefit the community as well as help to better position the company. Corporate philanthropy is gifts given by companies to social and charitable causes, such as support for education, culture, or the arts; minorities or health care; or for relief funds for victims of natural disasters (Seifert et al. 2004; Godfrey 2005). Corporate philanthropy often extends beyond areas that are directly associated with a corporation's economic activities or legal requirements (Wang et al. 2008). According to Porter and Cramer (2002), philanthropy does not just address a company's self-interest it benefits many through broad social change. Another form of corporate social responsiveness is sponsorship. Sponsorship is engagement in societal or

Table 2. Corporate social responsiveness as organizational programs (source: Maignan, Ralston 2002)

\begin{tabular}{|l|l|}
\hline \multicolumn{2}{|l|}{ Corporate social responsiveness } \\
\hline $\begin{array}{l}\text { Philan- } \\
\text { thropic } \\
\text { programs }\end{array}$ & $\begin{array}{l}\text { The company presents a formalized philan- } \\
\text { thropy program made of a clear mission and } \\
\text { application procedures to allocate donations } \\
\text { and grants. }\end{array}$ \\
\hline $\begin{array}{l}\text { Sponsor- } \\
\text { ships }\end{array}$ & $\begin{array}{l}\text { The company introduces sponsorships as a type } \\
\text { of responsibility initiative aimed at providing } \\
\text { assistance either financial or in-kind to a cause } \\
\text { or charity. }\end{array}$ \\
\hline $\begin{array}{l}\text { Volun- } \\
\text { teerism }\end{array}$ & $\begin{array}{l}\text { The company presents programs that allow } \\
\text { employees to work for a good cause during paid } \\
\text { working hours. }\end{array}$ \\
\hline $\begin{array}{l}\text { Code of } \\
\text { ethics }\end{array}$ & $\begin{array}{l}\text { The company discusses the content and/or } \\
\text { implementation of a code of ethics or conduct. }\end{array}$ \\
\hline $\begin{array}{l}\text { Quality } \\
\text { programs }\end{array}$ & $\begin{array}{l}\text { The company describes a formal product/ } \\
\text { service quality program as a form of } \\
\text { responsibility initiative. }\end{array}$ \\
\hline $\begin{array}{l}\text { Health } \\
\text { and safety } \\
\text { programs }\end{array}$ & $\begin{array}{l}\text { The company introduces formal health and safety } \\
\text { programs aimed at one or more stakeholder } \\
\text { groups as a form of responsibility initiative. }\end{array}$ \\
\hline $\begin{array}{l}\text { Manage- } \\
\text { ment of en- } \\
\text { vironmental } \\
\text { impacts }\end{array}$ & $\begin{array}{l}\text { The company discusses activities aimed at } \\
\text { diminishing the negative impact of productive } \\
\text { activities on the natural environment. }\end{array}$ \\
\hline
\end{tabular}

local community activities to which a company provides support in the form of finance, know-how or other kinds of support. Sponsorship is not the same as philanthropic activity as often reckoned. Sponsorships are investments in cultural or social projects.

So it is planned actions on purpose to improve the image of the company and to increase the loyalty of potential customers. Volunteerism as organizational program is also a thoughtful and planned action. Volunteerism is far more likely than other kinds of helping to take place within an organizational setting. Volunteerism can be defined as longterm, planned, pro-social behaviors that benefit strangers and occur within an organizational setting (Penner 2002). As noticed Eckstein (2001), some businesses encouraged volunteerism on their own because they were so committed to the spirit of community. Volunteerism usually targets community issues. Other CSR processes as codes of ethics, health and safety programs addressed various stakeholder issues at the same time. Successful companies need a healthy society. Education, health care, and equal opportunity are essential to a productive workforce. Safe products and working conditions not only attract customers but lower the internal costs of accidents (Cunningham, Harney 2012). Socially responsible companies strive to provide safe and healthy work conditions as the foundation for promoting the well-being of their employees. Also businesses involve and commit to advancing good health and safety practices throughout operations and products because they take thought for the future and well-being of society. Code of ethics is one of the main tools for implementing CSR inside company, but also is a point of reference for relations between the company and society. According to Callaghan et al. (2012), "as ethics are deemed to be an embodiment of a society's moral values, then one's ancestry plays a pivotal role in the evolution of the current ethical values of one's society. Codes of ethics are the written codifications of these cultural self-perceptions and showcase to all who read them the underlying ethos of the company and its perception of the business culture of the country from which it emanates". The modern concept of the business ethics concerns the issue of the businesses' social responsibility, the setting of an adequate organizational culture, that should take into account not only the need of increasing the profit, the shareholders and associates' income, but also the achievement of all the social conditions that act within a society (Trifu 2011). Peddle and Rosam (2004) stated that CSR is not different from quality - both searching for success through careful balance. Socially responsible companies implement product/service quality programs to realize maximum customer like other stakeholder satisfaction. Companies' decisions to adopt environmental management practices are influenced by the desire to improve or maintain relations with their communities (Delmas, Toffel 2004). Adopting environmental 
management systems not only focuses a company's attention on negative environmental impacts but also ensures that responsibility is appropriately assigned for maintaining high environmental standards throughout the organization (Morrow, Rondinelli 2002). Companies implement organizational programs as processes of corporate social responsiveness to respond to social concerns and expectations. The implementation of corporate social responsiveness contributes to the consolidation of relationship between business and society and so it furthers the sustainable development of community, region and country.

\section{Corporate social responsiveness initiatives as organizational programs in Lithuania}

Lithuania, as a member of the European Union and contributing to the strategies "Europe 2020" and "Lithuania 2030" to create a smart, sustainable and inclusive economy, has approved CSR development vision and priority areas of its implementation. Agreeably to these strategies and other CSR initiatives promoting legal acts and with conscious of their social responsibility Lithuanian companies voluntarily assume additional obligations to improve business practices, introduce modern human resource management technologies, implement resource-saving and environment-friendly (mitigating climate change) technologies, invest in "green" technologies, products and services, use health harmless substances in manufacturing processes, harmonize labor relations and actively take part in the social dialogue. The long-term success of the companies depends on how harmoniously they are able to integrate into the environment and to evaluate the expectations of internal and external stakeholders - the relationship between the company and the surrounding environment should be formed on the basis of social responsibility. There is essential to regard the expectations of all stakeholders in putting into practice the strategies of corporate social responsibility. The development of socially responsible business is encouraged by the formed in the society culture of sociality and responsibility for their activities in the culture. According to the Čiegis (2009), CSR is measured and institutionalized not only on the basis of market and workplace parameters, but also public and environmental parameters.

The aim of the empirical study "The integration of corporate social responsibility into the strategies of international companies in Lithuania" (Kontautiene 2011) was to investigate the opinion of the experts about Lithuanian international companies' politics of corporate social responsibility integration and the benefits for companies and society.

According to the survey aim and the requirements for the experts, as experts were sampled the trade responsible for CSR projects from Lithuanian international companies. During the survey 32 answers to the questionnaires were got. Experts were asked to assess the importance of socially responsive programs realizable by Lithuanian companies. On the basis of experts' evaluation Lithuanian companies focus and give priority to programs of the quality and to management of the environmental impact and environmental programs (see Fig. 2). Their implementation is intense. Further, health and safety programs, codes of ethics, sponsorships, volunteering and philanthropic programs were grated according to importance. The quality programs, management of the environmental impact and environmental programs as very important and important socially responsive programs noted by 88 percent of the respondents (see Fig. 2). An implementation of quality management and environmental management standards into activities of businesses is very important for the integration of CSR. Quality management systems according to the ISO 9001 standards (International Organization for Standardization 2014a) and environmental management systems according to the ISO 14001 standards have gained recognition in Lithuania. Numbers of ISO 9001 and ISO 14001 certification have substantially increased in past few years (International Organization for Standardization 2014b; Lithuanian Standards Board 2014). According to Lithuanian Standards Board (2014), by the

Management of environmental impacts Health and safety programs Quality programs Code of ethics Volunteerism Sponsorships Philantropic programs

\begin{tabular}{|c|c|c|c|c|c|c|}
\hline \multicolumn{3}{|c|}{$53 \%$} & & $33 \%$ & \multicolumn{2}{|c|}{$12 \%$} \\
\hline \multicolumn{4}{|c|}{$41 \%$} & & $6 \%$ & $6 \%$ \\
\hline \multicolumn{4}{|c|}{$69 \%$} & & \multicolumn{2}{|c|}{$12 \%$} \\
\hline \multicolumn{4}{|c|}{$41 \%$} & & \multicolumn{2}{|c|}{$12 \% \quad 3 \%$} \\
\hline $16 \%$ & \multicolumn{3}{|c|}{$28 \%$} & $12 \%$ & & 9\% \\
\hline $9 \%$ & \multicolumn{3}{|c|}{$44 \%$} & $22 \%$ & & $3 \%$ \\
\hline $9 \%$ & \multicolumn{2}{|c|}{$25 \%$} & $35 \%$ & $22 \%$ & & $9 \%$ \\
\hline
\end{tabular}

Very important Important Average important $\square$ Not very important $\square$ Totally irrelevant

Fig. 2. Distribution of evaluation of socially responsive programs, in percent (source: Kontautiene 2011) 


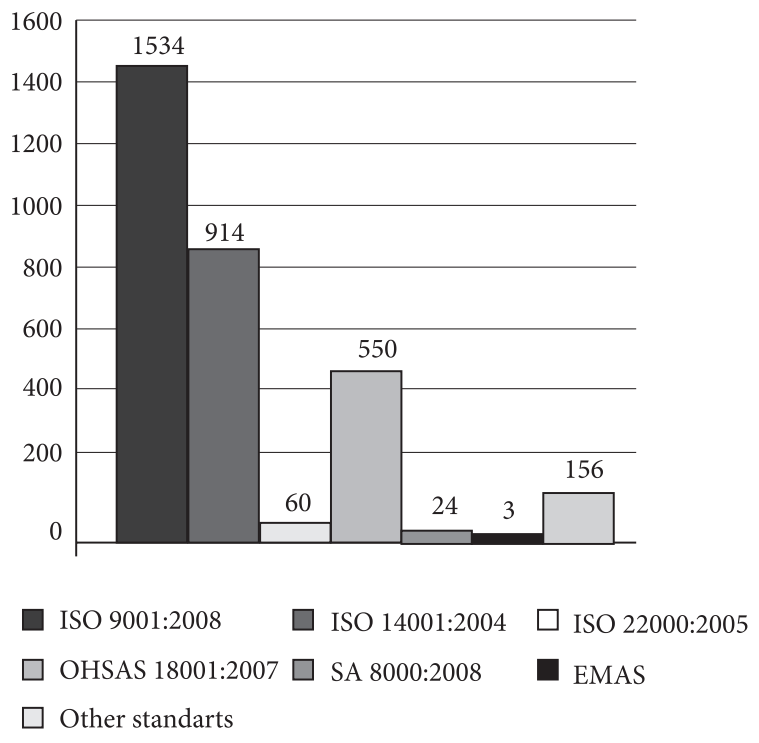

Fig. 3. Number of Lithuanian companies introduced management systems as per international standards (in units) (source: Lithuanian Standards Board 2014)

beginning of July 2014 ISO 9001 issued 1534 certifications and ISO 14001 issued 914 certifications across a wide range of organizations in the manufacturing, service and government sectors (see Fig. 3). However, there is still comparatively big number of companies which are not ISO 9001 and ISO 14001 certified in Lithuania.

Health and safety programs, codes of ethics as very important socially responsive programs evaluated 41 percent of experts. More than 45 percent of respondents have assessed these programs as important and significant on average. The majority of Lithuanian companies understand social responsibility as investing in occupational health and safety as well as in observing human rights (Jonkute et al. 2011; Matkeviciene 2013).

Certified occupational health and safety management systems OHSAS 18001, indicating that the company's operating system checked in accordance with the standard of best practice and meets the requirements, act in 550 Lithuanian companies (see Fig. 3). Philanthropic and sponsorship programs and participating in voluntary programs got least support from Lithuanian companies. Over 20 percent of the respondents these programs as corporate social responsiveness processes noted as not very important or irrelevant and as least company-funded programs in Lithuania.

In Lithuania the companies' participation in philanthropic activities is determined by the politics, culture and other factors, but not by rising income of companies. There is growing number of socially responsible companies in Lithuania, but the process run not so fast (Navickas, Kontautiene 2011). A socially responsible company should be responsible for each activity, which affects people, their communities and the environment. In summary it can be stated that Lithuanian companies pay the highest attention to quality programs and to management of the environmental impact and environmental programs, what was confirmed to the expert assessments. Philanthropic programs and volunteerism are mainly sponsored by big companies in Lithuania. An understanding of these programs usefulness and their process of implementation develops sufficiently heavily.

Socially responsible businesses in Lithuania respond to the expectations of the public and other stakeholders, and actively contribute to the solution of social and environmental problems, and further to the sustainable development of the regions and the whole country. There are a growing number of socially responsible enterprises in Lithuania, but the process of development of corporate social responsibility is not so fast. This requires a solid and coherent government formulated policy on CSR. The government of Lithuania recognizes that socially responsible business is consistent with the public welfare expectations, and is beneficial to the sustainable development of society and the country. CSR promotion policy in Lithuania does not secure an approval of public in terms of CSR and does not create strong incentives for businesses to implement the initiatives of corporate responsiveness. Nevertheless corporate social responsibility becomes more and more valuable in Lithuania and its future development mainly depends on the government and society of the country.

\section{Conclusions}

Corporate social responsibility as companies' responsibility for their impacts on society is based on three equally developing elements: economic, environmental and social. The development of main elements of CSR ensures the consolidation of relationship between the company and all groups of stakeholders. Business organization should maintain a sense of social responsibility for being accountable to any its action that affects environment and society. Corporate social responsibility is a set of activities that should be practiced by companies in order to cope with social and environmental problems and could be analyzed in two dimensions: internal (within the organization) and external (outside the organization).

Corporate social responsiveness is an action dimension of CSR. Processes of corporate social responsiveness as organizational programs are aimed at implementing CSR principles and addressing social and environmental concerns and expectations. Organizational programs such as quality management, environmental impact management, philanthropic, health and safety programs, sponsorship, volunteerism, are voluntarily realizable by companies on purpose to resolve social and environmental problems both inside and outside the companies. The implementation of processes of corporate social responsiveness benefits to 
improvement of public and business environment, and contributes to betterment the relationship between business and society and so furthers the sustainable development of region and country.

Lithuanian companies focus and give priority to development of the quality and the management of the environmental impact and environmental programs. Their implementation is more intense. Also they realize health and safety, ethics, sponsorships, volunteering, philanthropic programs. But a number of socially responsible companies, which implement organizational programs as corporate responsiveness processes, too small. In Lithuania the companies' participation in socially responsiveness activities is determined by the politics, culture and other factors, but not by rising income of companies. Socially responsible businesses in Lithuania respond to the expectations of the public and other stakeholders, and actively contribute to the solution of social and environmental problems, and further to the sustainable development of the regions and the whole country.

\section{Disclosure statement}

Authors don't have any competing financial, professional, or personal interests from other parties.

\section{References}

Callaghan, M.; Wood, G.; Payan, J. M.; Singh, J.; Svensson, G. 2012. Code of ethics quality: an international comparison of corporate staff support and regulation in Australia, Canada and the United States, Business Ethics: A European Review 21(1): 15-30.

http://dx.doi.org/10.1111/j.1467-8608.2011.01637.x

Campbell, J. L. 2007. Why would corporations behave in socially responsible ways? An institutional theory of corporate social responsibility, Academy of Management Review 32(3): 946-967. http://dx.doi.org/10.5465/AMR.2007.25275684

Carroll, A. B. 1979. A three-dimensional conceptual model of corporate performance, Academy of Management Review 4(4): 497-505. http://dx.doi.org/10.5465/AMR.1979.4498296

Crampton, W.; Patten, D. 2008. Social responsiveness, profitability and catastrophic events: evidence on the corporate philanthropic response to 9/11, Journal of Business Ethics 81(4): 863-873. http://dx.doi.org/10.1007/s10551-007-9553-7

Cunningham, J.; Harney, B. 2012. Strategy \& strategists. Oxford: Oxford University Press.

Čiegis, R. 2009. Gamtos ištekliu ir aplinkos ekonomika. Klaipėda: KU leidykla.

Dagiliene, L. 2010. The research of corporate social responsibility in annual reports, Engineering Economics 21(2): 197-204.

David, P.; Kline, S.; Dai, Y. 2005. Corporate social responsibility practices, corporate identity, and purchase intention: a dual-process model, Journal of Public Relations Research 17(3): 291-313. http://dx.doi.org/10.1207/s1532754xjprr1703_4
Delmas, M.; Toffel, M. W. 2004. Stakeholders and environmental management practices: an institutional framework, Business Strategy and the Environment 13(4): 209-222. http://dx.doi.org/10.1002/bse.409

Dentchev, N. A. 2004. To what extent is business and society literature idealistic?" [online], Working paper [cited 11 June 2014]. Available from Internet: www.feb.ugent.be/nl/Ondz/ wp/Papers/wp_04_245.pdf

Dillon, P. J.; Back, R. M.; Manz, C. C. 2014. Authentic corporate social responsibility based on authentic empowerment: an exemplary business leadership case, Journal of Values-Based Leadership 7(1): 12.

Eckstein, S. 2001. Community as gift-giving: collectivistic roots of volunteerism, American Sociological Review 66(6): 829-851. http://dx.doi.org/10.2307/3088875

European Commission. 2011. Communication from the Commission to the European Parliament, the Council, the European Economic and Social Committee and the Committee of Regions: A renewed EU strategy 2011-14 for Corporate Social Responsibility, COM (2011) 681 final, Brussels 25.10.2011.

Fieseler, C.; Fleck, M.; Meckel, M. 2010. Corporate social responsibility in the blogosphere, Journal of Business Ethics 91: 599-614. http://dx.doi.org/10.1007/s10551-009-0135-8

Friedman, M. T.; Parent, M. M.; Mason, D. S. 2004. Building a framework for issues management in sport through stakeholder theory, European Sport Management Quarterly 4(3): 170-190. http://dx.doi.org/10.1080/16184740408737475

Giziene, V.; Palekiene, O.; Simanaviciene, Z. 2011. State social responsibility in the context of knowledge-based economy, Economics and Management 16: 485-492.

Godfrey, P. C. 2005. The relationship between corporate philanthropy and shareholder wealth: a risk management perspective, Academy of Management Review 30(4): 777-798. http://dx.doi.org/10.5465/AMR.2005.18378878

International Organization for Standardization. 2014a. International Standards [online], [cited 30 June 2014]. Available from Internet: http://www.iso.org/iso/home.htm

International Organization for Standardization. 2014b. ISO Survey [online], [cited 30 June 2014]. Available from Internet: http://www.iso.org/iso/home/standards/certification/ iso-survey.htm?certificate $=\mathrm{ISO} \% 2014001 \&$ countrycode $=\mathrm{L}$ T\#standardpick.

Jonkute, G.; Staniskis, J. K.; Dukauskaite, D. 2011. Social responsibility as a tool to achieve sustainable development in SMEs, Environmental Research, Engineering and management 57(3): 67-81.

Kontautiene, R. 2011. The integration of corporate social responsibility into the international companies' strategies: Master's work. Kaunas University of Technology, Kaunas.

Maignan, I.; Ferrell, O. C. 2001.Corporate citizenship as a marketing instrument-concepts, evidence and research directions, European Journal of Marketing 35(3/4): 457-484. http://dx.doi.org/10.1108/03090560110382110

Maignan, I.; Ralston, D. A. 2002. Corporate social responsibility in Europe and the U.S.: insights from businesses' self-presentations [online], [cited 30 June 2014]. Available from Internet: http://ufirc.ou.edu/publications/Corporate $\% 20$ Social\%20 Responsibility.pdf 
Maignan, I.; Ferrell, O. C. 2004. Corporate social responsibility and marketing: an integrative framework, Journal of the Marketing Science 32(1): 3-19. http://dx.doi.org/303258971

Maignan, I.; Ferrell, O. C.; Ferrell, L. 2005. A stakeholder model for implementing social responsibility in marketing, European Journal of Marketing 39(9/10): 956-977. http://dx.doi.org/10.1108/03090560510610662

Matten, D.; Crane, A.; Chapple, W. 2003. Behind the mask: revealing the true face of corporate citizenship, Journal of Business Ethics 45(1-2): 109-120. http://dx.doi.org/10.1023/A:1024128730308

Matkeviciene, R. 2013. Communication of corporate social responsibility in Lithuanian organizations' websites, Information Sciences 64: 7-18.

Maurer, M. 2007. Corporate stakeholder responsiveness: an evolutionary and learning approach. HauptVerlag AG.

Mohr, L. A.; Webb, D. J.; Harris, K. E. 2001. Do consumers expect companies to be socially responsible? The impact of corporate social responsibility on buying behavior, Journal of Consumer Affairs 35(1): 45-72. http://dx.doi.org/10.1111/j.1745-6606.2001.tb00102.x

Morrow, D.; Rondinelli, D. 2002. Adopting corporate environmental management systems: motivations and results of ISO 14001 and EMAS certification, European Management Journal 20(2): 159-171. http://dx.doi.org/10.1016/S0263-2373(02)00026-9

Navickas, V.; Kontautiene, R. 2011. Influence of corporate philanthropy on economic performance, Business: Theory and Practice 12(1): 15-23. http://dx.doi.org/10.3846/btp.2011.02

Navickas, V.; Kontautiene, R. 2012. The influence of stakeholder - company relationship on competitiveness of company, Economics and Management 17(3): 1010-1015. http://dx.doi.org/10.5755/j01.em.17.3.2111

Lithuanian Standards Board. 2014. Certification [online], [cited 20 July 2014]. Available from Internet: http://www.lsd.lt/ typo_new/index.php?id=157.

Lockett, A.; Moon, J.; Visser, W. 2006. Corporate social responsibility in management research: focus, nature, salience and sources of influence, Journal of Management Studies 43(1): 115-136. http://dx.doi.org/10.1111/j.1467-6486.2006.00585.x

Logsdon, J. M. 2004. Global business citizenship: applications to environmental issues, Business and Society Review 109(1): 67-87. http://dx.doi.org/10.1111/j.0045-3609.2004.00004.x

OECD. 2011. OECD Guidelines for Multinational Enterprises 2011 edition. OECD Publishing. http://dx.doi.org/10.1787/9789264115415-en
Peddle, R.; Rosam, I. 2004. Finding the balance, Quality World 16: $18-26$

Penner, L. A. 2002. Dispositional and organizational influences on sustained volunteerism: an interactionist perspective, Journal of Social Issues 58(3): 447-467. http://dx.doi.org/10.1111/1540-4560.00270

Porter, M. E.; Kramer, M. R. 2002. The competitive advantage of corporate philanthropy, Harvard Business Review December 2002: 5-16.

Pruskus, V. 2003.Verslo etika: laiko iššūkiai ir atsako galimybès. Vilnius: Enciklopedija.

Quazi, A. M. 2003. Identifying the determinants of corporate managers' perceived social obligations, Management Decision 41(9): 822-831. http://dx.doi.org/10.1108/00251740310488999

Ruzevicius, J.; Serafinas, D. 2007. The development of socially responsible business in Lithuania, Engineering Economics 1(51): 36-43.

Seifert, B.; Morris, S. A.; Bartkus, B. R. 2004. Having, giving, and getting: slack resources, corporate philanthropy, and firm financial performance, Business \& Society 43(2): 135-161. http://dx.doi.org/10.1177/0007650304263919

Sethi, S. P. 1979. A conceptual framework for environmental analysis of social issues and evaluation of business response patterns, Academy of Management Review 4(1): 63-74. http://dx.doi.org/10.5465/AMR.1979.4289184

Streimikiene, D.; Kovaliov, R. 2007. Corporate social responsibility in Baltic States, Ekonomika ir vadyba: aktualijos ir perspektyvos 2(9): 285-293.

Trifu, A. 2011. Approach regarding the influence of business ethics on corporate governance [online], [cited 11 June 2014]. Available from Internet: http://ices.ro/RePEc/zan/ ygzier/2011/2011_1_09_Anuar_Tomul20_Trifu.pdf

Waddock, S. 2004. Parallel universes: companies, academics, and the progress of corporate citizenship, Business and Society Review 109(1): 5-42. http://dx.doi.org/10.1111/j.0045-3609.2004.00002.x

Wang, H.; Choi, J.; Li, J. 2008. Too little or too much? Untangling the relationship between corporate philanthropy and firm financial performance, Organization Science 19(1): 143-159. http://dx.doi.org/10.1287/orsc.1070.0271

Wood, D. J. 1991. Corporate social performance revisited, Academy of Management Review 16(4): 691-718. http://dx.doi.org/10.5465/AMR.1991.4279616

Valentinas NAVICKAS. Doctor of social sciences (economics), professor at Kaunas University of Technology (Lithuania), School of Economics and Business, Department of Economics.

Author of more than 280 scientific publications (including monograph published in Czech Republic, 2013) and scientific articles, published in Lithuania and abroad, author of four experimental development projects,prepared4 doctors of social (economics) science; now he is research adviser of 2 persons maintaining a doctor's thesis of social (economics) science.

Fields of scientific interest: international economics, tourism economics, clusterization, competitiveness, customer satisfaction, corporate social responsibility.

Rima KONTAUTIENĖ. PhD student at Kaunas University of Technology, School of Economics and Business, Department of Economics. Fields of scientific interest: microeconomics, macroeconomics, international economics, corporate social responsibility, corporate philanthropy. 